\title{
The Problem of Students in Reading the Quran: A Reflective-Critical Treatment through Action Research
}

\section{Tedi Supriyadi}

Universitas Pendidikan Indonesia, Indonesia, tedisupriyadi@upi.edu

\section{J. Julia}

Universitas Pendidikan Indonesia, Indonesia, juli@upi.edu

To improve the skill in reading the Quran correctly, students need to be given skills in learning to read the Quran quickly and effectively so that they can know the Arabic alphabet well, pronounce it correctly, understand the elocution of reading, and understand its meaning well. The action research report presented in this journal article exemplifies the collaborative teamwork involved in making the reflective-critical steps to improve the students' skill from their initial state of being unable to read the Quran smoothly to being able to master its elocution. The subjects of the research were 126 second semester students of Nursing Study Program. The results of the actions showed an improvement in students' skill to read the Quran with a students' skill change rate that reached $90.20 \%$, and with the success rate of students switching from the non-fluent category to the fluent category of reading the Quran that reached $65.08 \%$.

Keywords: muslim student, reading skill, reading Quran, tahqiq method, Quran recitation,

\section{INTRODUCTION}

Indonesia basically adopts a 6-3-3-4 school-based education system consisting of 6 years of primary and 3 years of junior secondary, 3 years of senior secondary, and 4 years of tertiary education (undergraduate degree) (Mukminin, Rohayati, Putra, Habibi, \& Aina, 2017, p. 37). Islamic Religious Education (PAI, Pendidikan Agama Islam) is given during each of education level. In other words, for basic education system in Indonesia, PAI is given to the students for 12 years, and it can increase to 14 years or more if the pre-school education is calculated. That is an ideal time for Muslims to learn to read the Quran in a formal school until they can master it well, even to the point of understanding the Quran well and correctly. However, the results of a preliminary study in one of the departments at the university in Sumedang Regency, West Java Province, 
Indonesia, showed that among 320 Muslim students from three batches (2016-2018), in which each batch consisted of three classes, there were $70 \%$ students from each class who could not read the Quran correctly. This fact was a blow to the world of formal education in Indonesia, especially in PAI subjects that has direct contact with Quran reading lesson.

Reading the Quran cannot be overlooked in the life of Muslims especially for the faithful adherents. The Muslims believe that Islam is a complete way of life and gives clear direction on how to live a life and build a society (Aziz \& Ambreen, 2017, p. 331). The main guidance for the Muslims is the Quran, which is then combined with the Hadith as explanation and the revelation of the Quran derived from the messenger of Allah, which is Prophet Muhammad SAW. To be able to understand the instructions in the Quran, it is certain that every Muslim should be able to read it, and then must understand the readings well and correctly as well. It means that the inability to read the Quran will have an impact on the inability to understand the Qur'an, and that could have an impact on not being able to take clues from the Quran.

Reading the Quran must be correct so it needs to be done with utmost care and no mistakes (Muhammad, ul Qayyum, Tanveer, Martinez-Enriquez, \& Syed, 2012). When a Muslim in a university level cannot read the Quran correctly, then this becomes a serious problem, not only for the Muslims concerned, but also for the Islamic religion as a whole. In Islam, the Quran is a guideline to implement the Islamic Shari'a, meanwhile, one of the goals of the Islamic Shari'a is to keep the religion (Al-Shatibi, 2003). Thus, a Muslim who cannot read the Quran, is the same as a Muslim who cannot properly run the Islamic Shari'a, so it can be called as a Muslim who has the potential to undermine Islam religion. In response to these issues, this research aims at developing students' skill in reading the Quran through reflective-critical treatments, to become fluent and to be better in living a life as a Muslim.

Some of the previous research results also seek to improve the reading skills of the Quran in various ways. Yusof, Zainuddin, and Yusoff (2011) conducted a survey to identify the problems in reciting the Quran for Arabic speakers (Malay and Africans) and non-Arabic speakers (Malay). The results showed that there was evidence that fluency of recitation, remembering Tajweed rules, and comprehending the words in the Quran increased with the skill to speak the Arabic language. The higher level of reciters of the Quran means the lesser problems encountered in their recitation and problems encountered by the reciters of Quran can be reduced by increasing the general learning method i.e. making more effort towards learning Quran or providing the alternative methods on learning Qur'an.

This research has taken practical steps by prioritizing the direct reflective-critical action, so that the results can be examined directly. The possibility, by applying the actions according to the situation and conditions that occur, can create a new method in eradicating inability to read the Quran, especially for college students or adult Muslims. It is expected that this action can establish proper and fluent basic Quran reading to the research participants, such as (1) reading cursive letter fluently and correctly, (2) reciting the makhraj fluently, and (3) applying the tajweed correctly. 


\section{Obligation to Read and Study the Quran in Islam}

Studying the Quran is an obligation (Shihab, 2007) for Muslims. According to Yunus (1983), there are three important points in the purpose of learning the Quran. First, students can read the Quran fluently and correctly according to Tajweed. Second, students can get used to reading the Quran in their life. Third, students can enrich the vocabulary of beautiful and compelling words and phrases. To encourage the improvement of skills in reading the Quran, proper learning is required. There are at least six points that can be used as a reference for learning the Quran, which are: (1) the introduction of Arabic alphabet in the Quran from alif to the ya; (2) makhärij al-hurüf, which is the guidance to the sound the alphabet and the properties of the alphabet; (3) form, function, and punctuation such as harakah, shadda, sukūn, and the prolongation of the alphabet; (4) form and function of waqf (Arabic stop sign in reading the Quran); (5) the method of Quran reading and recitation of qira'at and nagham; and (6) adabuttilawah, which is the courtesy when reciting the Quran (Daradjat, 2014).

There are several levels in reading Al-Quran, which are: Tartil, Tahqiq, Tadwir, and Hadr. Although the way to read quickly and lightly, the matter must be in accordance with the standards of sahīh known by qira'at experts (Syarifuddin, 2004). For beginners, first and second levels are the recommended reading levels. However, the ideal way that needs to be practiced in reciting the Quran according to the advice of the 'ulama is tahqiq as revealed by Imam Al-Suyuti that "every tahqiq must be tartil and not every tartil is tahqiq" (Suyuthi, 2010).

\section{METHOD}

\section{Research Design}

This research employs action research design. Many examples of action research approaches exist in educational and specifically academic library literature (Jefferson, 2014; Marrow, 1977). Here, exploring a practical problem with the intention of developing a solution to the problem (Creswell, 2015) was employed. In conducting the research, collaborative principles especially in the application of solutions as a criticalreflective action was used. Research that employed collaborative action research processes in education involve collaboration between teachers, or between teachers and researchers (Feldman, 1999; Messiou, 2018). Collaboration in this research involved the researchers (who were lecturers or educators of Islamic religion subject), peers who had expertise in music because this research used a series of melodies in the learning process of the Quran, and 10 selected students who had the skill to read the Quran at the level of Jayyid Jidan (excellent). In problem solving and development of action, in addition to observing the learning process, the preliminary and final tests in reciting the Quran were conducted, and training 10 selected senior students to assist in implementing and developing action as supervisor (tutor). 


\section{Research Site and Subjects}

The research was conducted in one of the state universities located in Sumedang Regency, West Java Province, Indonesia. This site was selected based on two considerations, namely: (1) The researchers were the lecturers of this university; hence, it increased the feasibility of the research; and (2) It represented the Quran reading ability of students in Sumedang City, Indonesia, so the results of this action research can be used as a proposed method to teach Quran to adult students in other areas of Indonesia. The subjects of the research were 126 second semester students of Nursing Study Program. Their place of origin was quite diverse, 121 (96.03\%) people were from Sumedang Regency, 4 (3.17\%) people were from Bandung Regency, and $1(0.80 \%)$ people was from Kuningan Regency.

\section{Data Collection and Analysis}

The data were collected using several techniques, including: (1) survey instruments at the pre-action stage to identify the Quran reading experience, the method of reading the Quran, and the motivation of learning to read the Quran; (2) observation was done to observe the learning process of reading the Quran through the actions given; (3) semistructured interviews were conducted to elicit students' opinions about their condition in relation to their reading skills of the Quran, and to explore their views after following a series of actions; and (4) the Quran reading skill test was performed during pre-test and post-test to find out the initial condition and the final result of giving the action.

\section{The Development of Quran Reading Indicators}

To identify students' Quran reading skills, the categorizations, levels, and indicators at each level were developed. Basically, there are five categories of reading skill, which are: not very fluent, not fluent, substandard, fluent, and very fluent. The five categories are divided into five levels, which are the level of Ibtida 1 (basic 1), Ibtida 2 (basic 2), Ibtida 3 (basic 3), Jayyid (good), and Jayyid Jidan (excellent). Indicators of those five levels are presented in Table 1 below. 
Table 1

Quran Reading Skill Indicators

\begin{tabular}{|c|c|c|}
\hline Level & Key Features & Category \\
\hline Ibtida 1 & $\begin{array}{l}\text { Cannot recognize stand-alone Arabic letters with its vowel } \\
\text { Can recognize stand-alone Arabic letters but sometimes the letters are swapped } \\
\text { Can read the stand-alone Arabic letters but cannot read the cursive letters }\end{array}$ & $\begin{array}{l}\text { Not very } \\
\text { fluent }\end{array}$ \\
\hline Ibtida 2 & $\begin{array}{l}\text { 1. Can read the cursive letters but it is limited to } 3 \text { to } 4 \text { letters } \\
\text { 2. Can read the cursive letters but the makhraj is still wrong or swapped } \\
\text { 3. Can read the letters but slowly or haltingly }\end{array}$ & Not fluent \\
\hline Ibtida 3 & $\begin{array}{l}\text { 1. Can read the cursive letters fluently and correctly } \\
\text { 2. The reading is not slow or halting } \\
\text { The application of } \underline{\text { Tajweed }} \text { is still wrong }\end{array}$ & Substandard \\
\hline Jayyid & $\begin{array}{l}\text { Can read the cursive letters fluently and correctly } \\
\text { 1. Can recite the makhraj fluently } \\
\text { 2. The application of Tajweed is correct } \\
\text { 3. } \quad \text { Know a little bit about Tajweed theory }\end{array}$ & Fluent \\
\hline $\begin{array}{l}\text { Jayyid } \\
\text { Jidan }\end{array}$ & $\begin{array}{l}\text { Can read the cursive letters fluently and correctly } \\
\text { Can recite the makhraj fluently } \\
\text { The application of Tajweed is correct } \\
\text { Understand the theory of Tajweed } \\
\text { Can read the Quran with rhythm }\end{array}$ & Very fluent \\
\hline
\end{tabular}

\section{FINDINGS}

\section{Pre-Action Analysis and Evaluation}

A total of 126 students who became the subject of research, were given survey instruments using Guttman scale. This survey was basically given to determine their experiences and perceptions of how they learn to read the Quran, their learning outcomes, and their further desires regarding their skill to read the Quran. The results of the survey can be seen in Table 2 below.

Table 2

The Learning Experience of Reading the Quran

\begin{tabular}{lll}
\hline Learning Experience of Reading the Quran & Yes & No \\
\hline Have you ever learned to read the Quran? & 126 & \\
Did you learn to read the Quran in a formal school? & 102 & 24 \\
Did you learn to read the Quran other than in formal school? & 107 & 19 \\
Can you read the Quran fluently? & 77 & 49 \\
\hline
\end{tabular}

Table 2 above reveals that all students have learned to read the Quran, even they learn to read the Quran not only in formal school but also outside their formal school. Here, it can also be seen that students who claimed to have been fluent in reading the Quran were $77(61.11 \%)$ students. In other words, the remaining $49(38.89 \%)$ students have not acquired the skill to read the Quran fluently. This data explained that the number of students who have been fluent in reading the Quran were more than the number of students who have not acquired the skill to read the Quran fluently. However, this data has not been proven by a direct reading of the Qur'an, so that their exact level of literacy in reading the Qur'an have not been tested yet. 
After the students' Quran reading skill based on their experience and recognition was identified, students were then assigned to review statements on a Likert scale. This assignment aims at knowing the efficacy of learning methods of reading the Quran that have been taken by them, and the extent of their motivation or desire to learn further to be able to read the Quran better.

Table 3

Quran Reading Learning Method

\begin{tabular}{|c|c|c|c|c|c|}
\hline Quran Reading Learning Method & $\begin{array}{l}\text { Very } \\
\text { Disagree }\end{array}$ & Disagree & $\begin{array}{l}\text { Slightly } \\
\text { Agree }\end{array}$ & Agree & $\begin{array}{l}\text { Very } \\
\text { Agree }\end{array}$ \\
\hline $\begin{array}{l}\text { Learning method of reading the } \\
\text { Quran given from elementary school } \\
\text { until high school can make students } \\
\text { read the Quran fluently. }\end{array}$ & & 4 & 24 & 64 & 34 \\
\hline $\begin{array}{l}\text { Additional hours outside the formal } \\
\text { school should be implemented to be } \\
\text { able to read the Quran fluently. }\end{array}$ & 1 & 4 & 15 & 65 & 41 \\
\hline $\begin{array}{l}\text { The learning method of Quran } \\
\text { reading outside formal school is faster } \\
\text { to make the students to be able to read } \\
\text { the Quran fluently. }\end{array}$ & & & 16 & 72 & 38 \\
\hline
\end{tabular}

Based on the students' statements based in Table 3, most students have agreed that the learning method of reading the Quran given at primary and secondary level was able to make them to read the Quran fluently. However, their statement also indicated uncertainty, as most students also agreed on the need for additional hours outside formal school to learn to read the Quran. This was evidenced by their last statement, which most students agreed that the learning method of reading the Quran outside of formal school was more effective to make them read the Quran fluently.

Referring to their uncertain statements, the students' Quran reading was tested directly to get a clearer and more accurate insight of their skill. The Quran reading test was done to all students (one by one) and the material was the Quran surah Shad verses 1 through 15. This surah was chosen because it contains huruful muqotho'ah and is sufficiently representative to check the mastery of reading and makhraj rules. The test results proved that $96(76.20 \%)$ of the students could not read the Quran fluently, and the rest of the 30 (23.80\%) students could be categorized as a fluent reader of the Quran. Thus, this data showed the inverse condition with the admission of students on the survey of learning experiences of reading the Quran (Table 2), and proving uncertainty on their statement in the survey of learning methods of reading the Quran (Table 3). Through this fact, it is certain that most students needed to be given action so that their skill to read the Quran can develop well.

Furthermore, the students were asked to return to rate the statements in Likert scale. It aims at finding out the extent of their motivation or desire to learn further to be able to read the Quran properly and fluently. 
Table 4

Learning Motivation to Read the Quran

\begin{tabular}{|c|c|c|c|c|c|}
\hline $\begin{array}{l}\text { Learning Motivation to Read the } \\
\text { Ouran }\end{array}$ & $\begin{array}{l}\text { Very } \\
\text { Disagree }\end{array}$ & Disagree & $\begin{array}{l}\text { Slightly } \\
\text { Agree }\end{array}$ & Agree & $\begin{array}{l}\text { Very } \\
\text { Agree }\end{array}$ \\
\hline $\begin{array}{l}\text { The skill to read the Quran fluently is } \\
\text { very important to master. }\end{array}$ & & & & 24 & 102 \\
\hline $\begin{array}{l}\text { Learning to read the Quran needs to } \\
\text { be done even in adulthood. }\end{array}$ & & 1 & 4 & 27 & 97 \\
\hline $\begin{array}{l}\text { Only ustadz and Muslim religious } \\
\text { leaders that need to be able to read } \\
\text { the Quran fluently. }\end{array}$ & 80 & 28 & 14 & 3 & 1 \\
\hline
\end{tabular}

Based on Table 4, it can be identified that the students had formed a strong opinion on the importance of being able to read the Quran fluently, and the need to learn to read the Quran even in adulthood. In fact, most students also agreed that not only religious leaders who need to be able to read the Quran fluently. They also needed to be able to read Quran properly and fluently.

The result of reflection on the problems and statements of students showed that it was necessary to act to solve the remainder in the students' skill of reading the Quran. Basically, they were already categorized as an adult, but considering reading the Quran is an obligation for them as Muslims, then learning to read the Quran still need to be done even in their age. Therefore, a series of actions consisting of six stages were performed.

\section{Critical Actions and Evaluations on Reading the Quran}

Pre-action analysis has resulted in six stages of learning to read the Quran. These six stages also involve reflective-critical and practical steps in every implementation. The following presents the six stages in which each stage is accompanied by diligent observation to observe students' responses.

\section{Stage 1: Mapping the Quran Reading Skills}

The results from the Quran reading test clearly proved that most of the students could not read the Quran fluently. To find out the specific classification or the level of reading skill, then the mapping of the Quran reading skills of the students based on the results of the initial test of reading the Quran was done. The mapping or classification results show the following data.

Table 5

Initial Test Results of Reading the Quran

\begin{tabular}{lll}
\hline Level & Total & Percentage \\
\hline Ibtida 1 & 11 & $8.73 \%$ \\
Ibtida 2 & 49 & $38.89 \%$ \\
Ibtida 3 & 36 & $28.57 \%$ \\
Jayyid & 30 & $23.81 \%$ \\
Jayyid Jidan & 0 & $0.00 \%$ \\
\hline
\end{tabular}


Table 5 shows that from 126 students, students who were categorized in the fluent category (Jayyid \& Jayyid Jidan) were 30 (23.81\%) students and none of them was at the level of Jayyid Jidan. Meanwhile, the students who were in the category of not fluent (Ibtida 1-3) were taking the highest with 96 (76.19\%) students, and the classification were: $11(8.73 \%)$ students were on the level of Ibtida 1, $49(38.89 \%)$ students were on the level of Ibtida 2, and $36(28.57 \%)$ students were on the level of Ibtida 3. This clearly indicates an apprehensive condition and requires remedial action to improve their skill to read the Quran. This condition is basically similar to the results of other similar research, such as Aliyah (2017)_and Jamhuri (2017) research. After finding out their category and level of the skill to read the Quran, the next action was to make a classification of study groups.

\section{Stage 2: The Classification of Quran Reading Study Groups}

Referring to data from preliminary test results, students' Quran reading skills were classified. From the grouping result, 10 groups were formed, with each group accompanied by a mentor who was part of the collaboration team. The level of Ibtida 1 was divided into two groups, and each group had five members. The level of Ibtida 2 was divided into five groups, and each group had 10 members. The level of Ibtida 3 was divided into three groups, and each group had 12 members. The Jayyid level was formed into one group, and the group had 30 members.

The Ibtida 1 level group had the least members because the material was still in basic category and it required more attention given the skill of students in reading the Quran was also still very basic. While the next level had more members of the group, because the material was not so basic and it did not need the attention of the mentor as in Ibtida 1 group. It was the same with the group in the Jayyid level, because they had entered the category of fluent in reading the Quran, so that the number of members of the group was more than the other level. Students in Jayyid level were considered to be perfecting only certain parts of reading the Quran.

\section{Stage 3: Learning to Read the Quran}

Students were taught about the pronunciation of self-disclosure non-syakal Arabic alphabets, the pronunciation of Arabic alphabets with vowels, shadda, and sukūn, reading the cursive letters, reading the words that contain alif läm qamarìyah and alif läm shamsiyah, the prolongation of the Arabic alphabets, and the theory of tajweed. For Ibtida 1 and Ibtida 2 level groups, the students were given a level 1 series book compiled by the researchers containing the material of self-disclosure non-syakal Arabic alphabets, Arabic alphabets with fathah, kasrah, and dammah vowels, and Arabic alphabets with tanwin fathah, kasrah, and dammah vowels, with sukun, and with shadda. Meanwhile, the students who of Ibtida 3 level groups were given a level 2 series book that contain the material of the prolongation of Arabic alphabets, nün sākinah, waqf, qalqalah, mìm and nūn shadda, mìm sākinah, tafkhìm, tarqīq, and idghām.

The learning outcomes of Ibtida 1 and 2 levels with level 1 series book took eight meetings, and the learning outcomes of Ibtida 3 level with the level 2 series book took 
five meetings. Meanwhile, the students who were classified into the level of Jayyid managed to improve their skill within five meetings. In this learning process, there was no self-training at home as a form of reinforcement, so some material needed to be repeated. The mentor should work harder in delivering the material in details, including how to exemplify pronunciation, such as practicing idghām that should contain buzzing sound. Sometimes students did not know what the humming buzz is, so it should be exemplified directly by the mentor.

The problems arose in the level of Ibtida 1 and 2 students, where few students were rarely present because they felt inferior with the fact that they were still at the most basic level. The problem also included a small part of students that remained at the same level as their condition in the pre-test. This was due to their very low attendance and low motivation so that there was no spirit to change, and their energy that was already drained in the lecture sessions so that their understanding when learning the Quran was weak. Fixed or static level positions inhibit the learning of other students. Nevertheless, most students succeeded in increasing their learning motivation so that they succeeded in improving their skill to read the Quran.

\section{Stage 4: Habituation and Memorization of Reading the Quran}

Students were given pronunciation exercises to familiarize in pronouncing makhraj by using syllables as follows:

Example 1. Arabic alphabet Alif

Example 2. Arabic alphabet $B a$

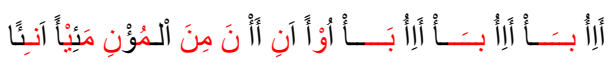

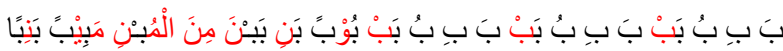

Example 3. Arabic alphabet $T a$

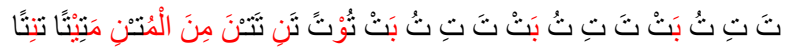

The red letters were unchanged letters in every word phrase sequence, it is just adjusting the way their pronunciation with the letters that are trained. For example, in the exercise of letter of 1 - letter of $\varphi$ (the first red letter) it will be read as $b a$, in the exercise of the letter of $ب$ it will be read $b a b$, and in the exercise of the letter of $ت$ it will be read bat, and so on. Meanwhile, the black letters were changing according to the sequence of the Arabic alphabet. In other words, after the three examples of the letters above, the habituation in pronouncing the makhraj will be followed by the onward Arabic alphabet from the letter of 1 until the letter of.

All syllables that are spoken, were trained by using melodies to make it easier to remember because the melody of a song can facilitate learning and recall (Konantz, 2012; Wallace, 1994). The following melodies were sung in learning to pronounce makhraj: 


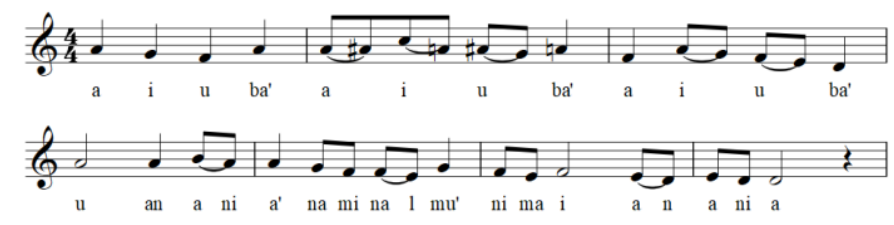

Figure 1

The melody of Arabic alphabet Alif

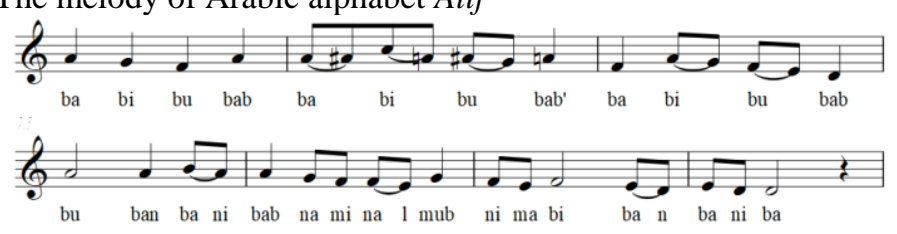

Figure 2

The melody of Arabic alphabet $B a$

The melody in Figure 1-2 are a series of melodies commonly used in some boarding school or in Quran learning center for children especially in the province of West Java, Indonesia, with the same function as in this research, which is to train learners to quickly remember and properly pronounce the makhraj. This method was effective in improving the learner's skills in pronouncing makhraj, as it has been experienced by the researchers themselves. So as in this research, through practice with syllables and melodies above, students could remember more quickly and able to distinguish the similar but not the same in pronunciation techniques Arabic alphabets. For example, the Arabic alphabet of $\omega$ with $\dot{\omega}$ and $\dot{\omega}$, the Arabic alphabet of $ح$ with $\dot{\tau}$ and $\rightarrow$, the Arabic alphabet of I with $\varepsilon$, the Arabic alphabet of د with $\dot{\dot{j}}$, and the Arabic alphabet of ض ض

\section{Stage 5: Examination and Strengthening the Quran Reading Skill}

The teaching team conducted examination of students' skill in subtest form on each material given before final or posttest. The objective was to observe the mistakes in implementing the reading rules that appears when they read the Quran, and to be further rectified and reminded. Each mentor conducted tests to students by directly reading the Quran with different surah. The results of the examination show that the results vary according to the level of students' skill in reading the Quran. For example, for the students in the level of Ibtida 1, when they were being tested, they were already able to read the cursive letters, but still stuttered. For the students in the level of Ibtida 2, they could read the cursive letters fluently, but the application of Tajwid was still wrong. Then, for the students in the level of Ibtida 3, they could read the Quran fluently and the reading had been accompanied by the right application of the Tajwid, but the theory of Tajwid are not yet fully mastered.

Based on the results of the investigation, several actions were carried out. For example, for students who were still pronouncing the makhraj wrong, they were reinforced with pronunciation practice through imagery techniques. For example, the sound of $\tau$ was likened to the sound of $h a$ in the word "Hug". It is the same for students who were 
categorized in basic level. They sometimes forgot the form of letters, so they were being reminded through symbols. For example, the letter 1 is symbolized with a pole, the letter 年 letters are symbolized with coconut buds, letters w is symbolized with toothbrush, and the letter $J$ is symbolized with a hook. This symbolization is enough to help students in reinforcing their memories of the Arabic alphabets.

\section{Stage 6: The Final Test of Reading the Quran}

All students who had followed the learning stages of reading the Quran, both who were always present and rarely present, were tested again for their progress in reading the Quran. The final test was performed and assessed directly by the researchers. The test results show the following data.

Table 6

The Final Test Results of Reading the Quran

\begin{tabular}{lll}
\hline Level & Total & Percentage \\
\hline Ibtida 1 & 0 & $0.00 \%$ \\
Ibtida 2 & 6 & $4.76 \%$ \\
Ibtida 3 & 38 & $30.16 \%$ \\
Jayyid & 52 & $41.27 \%$ \\
Jayyid Jidan & 30 & $23.81 \%$ \\
\hline
\end{tabular}

Table 6 above depicts that there was a progress of students' skill in reading the Quran. This significant progress can be seen in the number of students who entered the fluent category of reading the Quran (Jayyid \& Jayyid Jidan), which amounted to $82(65.03 \%)$ students, with $52(41.27 \%)$ students were classified at the level of Jayyid, and 30 $(23.81 \%)$ students were classified at the level of Jayyid Jidan. Meanwhile, students who entered the category of not fluent in reading the Quran (Ibtida 1-3) were amounted to 45 $(35.71 \%)$ students. The numbers of students that entered the category of not fluent in reading the Quran was still quite a lot. However, students' skill level specifically improved, because the numbers of students who could read the Quran fluently were more than the one who could not read the Quran fluently. The changes of the students' skill level are depicted in Figure 1 below. 


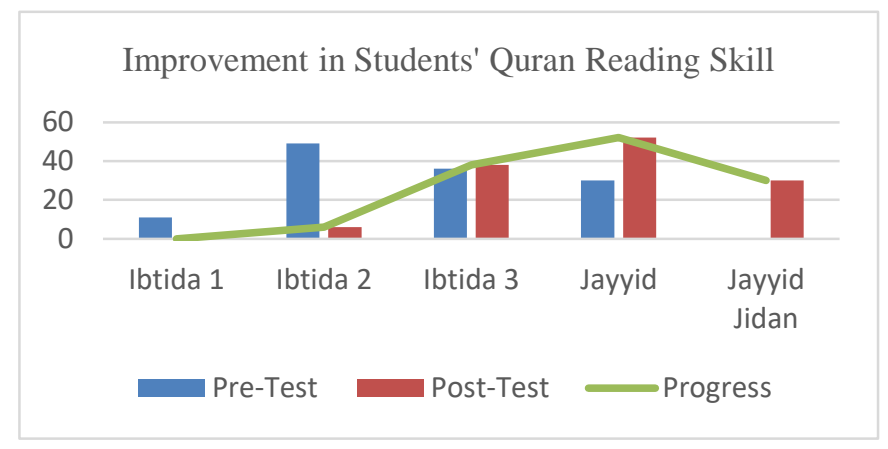

Figure 3

The Graph of Improvement in Students' Quran Reading Skill

Figure 3 above depicts a change in the level of students' skill to read the Quran. The results of pre-test and post-test proved that students at Ibtida 1 level were reduced by 11 so that there were no students left at this level, while students at Ibtida 2 level were reduced by 43 and six students remain at this level. Then, students at the level of Ibtida 3 increased to 38 students, this number represented a switch of students from Ibtida 1 and Ibtida 2 levels. Students who were previously at the level of Ibtida 3, all turned to the Jayyid level. As a result, students who were at the Jayyid level increased to 52 people. This number was not just students from Ibtida 3 level, but some students were from Ibtida 2 level and they successfully improved their skill to the Jayyid level. For the last level, the Jayyid Jidan, from the initial condition that had zero student, has increased to 30 students, and all of them were former students at Jayyid level.

\section{DISCUSSION}

\section{Post-Action Analysis and Evaluation}

The result of developing the action on the problem of the students' skill in reading the Quran, has successfully made changes to 125 (99.20\%) students. Most of the students switched level with the stepping pattern, and a small percentage of students experienced an improvement of level with the pattern of jumping. Students who succeeded in improving the level by jumping pattern were identified from Ibtida 1 to Ibtida 3 with five people (3.97\%), and from Ibtida 2 level to Jayyid with 16 (12.70\%) people. Based on this data, it can be identified that students, who were stagnant or unchanged, occurred in Ibtida 2 level that was only one person $(0.80 \%)$.

A thorough interview was done to the student who experienced stagnation levels in reading the Quran. The student's attendance data showed that the student did not attend the targeted 14 meetings of learning process. The student was recorded only attended the learning process four times. The researchers asked, "What caused the student to be present only four times?" The answer was the student was lazy to attend the learning process. The student was invited to play by the student's friends. The researchers also asked, "Did you know that reading the Quran is mandatory for a Muslim, and what are 
the consequences?" the answer was that the student knows the law is obligatory and will become sin if the student is not able to read it. Thus, the student was basically conscious of the actions, but the student had no sense of responsibility to study Islamic religion well.

Overall, the results of the evaluation showed that after the action was given, the remaining $6(4.76 \%)$ students was still in the non-fluent category in reading the Quran, and $38(30.16 \%)$ students were still less fluent in reading the Quran. They were basically making improvement with one move from lower to higher levels with an average of 12 meetings. This is what gives the belief to the researchers, that this learning process still must be continued with some subsequent meetings, so that there will be no more students who cannot read the Quran. Meanwhile, most of the 52 students $(41.27 \%)$ were in the fluent category of reading the Quran, and as many as $30(23.81 \%)$ of the students were in the category of very fluent reading of the Quran. The highest category was filled with students who were fluent in reciting the makhraj, applying tajwid correctly, understanding the theory of tajwid, and reading by using rhythm.

The results of this action research provided a new understanding, that to make learners able to read the Quran fluently did not require long time. This is evident in the students who followed this learning process. By being taught for several meetings, their skills increased significantly. The failure of teachers at the level of basic education by making learners unable to read the Quran correctly, is an evaluation and a reflection on their thinking that may have been seen as a successful teacher in teaching learners. In fact, according to Joyce, Weil, and Calhoun (2003), successful teachers are not just a charismatic and persuasive presenters. Further, successful teachers are those who engage students in cognitive and social loaded tasks and teach them how to do the tasks productively.

Teachers' lack of success in teaching learners to read the Quran can also be caused by the habit of teachers who teach unprofessionally, who teach in an instant way, and less concerned about the changes of the learners. In fact, teaching professional learning is a complex process, which requires cognitive and emotional involvement of teachers individually and collectively, the capacity and willingness to examine where each one stands in terms of convictions and beliefs and the perusal and enactment of appropriate alternatives for improvement or change (Avalos, 2011). Thus, basically teachers need to reflect themselves and need to know how teachers learn and change by developing theory or applying theory to the discussion of teacher change (Avalos, 2011; Clarke \& Hollingsworth, 2002). This suggests that teachers must also have literacy skills, at least tracing studies that can improve their skills, such as how teacher learning is researched and propose or discuss models of teacher professional learning (Avalos, 2011; James \& McCormick, 2009). More precisely, teacher are expected to try practicing an action research approach, because as the results an action research has proven to be a central approach to the investigation, reflection and improvement of practice (Gibbs et al., 2017).

This research has shown the fact that learning to read the Quran during elementary education has not succeeded in making the students able to read the Quran correctly, and 
the students in this research are the product of the unsuccessfulness. Nevertheless, by using reflective-critical treatments in learning to read the Quran with a collaborative process between researchers, peers, and senior students, then students who were not fluent in reading the Quran can improve their skill in reading the Quran. The actions that researchers done in six stages, were able to improve the Quran reading ability of 125 among 126 students. Therefore, action research can be used as an alternative in eradicating the ignorance of reading or illiteracy of the Quran especially at university level. It is in accordance with the results of similar studies that problems in reading the Quran can be reduced by improving the quality the Quran learning method or providing alternative method of Quran learning (Yusof et al., 2011).

The six steps done in this action research can be called as TAHQIQ (T=Telaah, $\mathrm{A}=$ Arahkan, $\mathrm{H}=$ Haluskan, $\mathrm{Q}=$ Qiroatkan, $\mathrm{I}=$ Ingatkan, $\mathrm{Q}=$ Qori) method, in other words Review, Navigate, Make it Fluent, Qiro'at, Remind, and Qori. In specific, review through mapping and skill classification. Navigate through the learning process of reading the Quran. Make it fluent and with Qiro'at through the steps of habituation and memorization in reading the Quran. Remind through examination and strengthening steps. Qori is the goal of all series of actions through the final test step of reading the Quran. In other words, a fluent Quran reader is referred to as Qori. These six steps can be used an alternative in developing the Quran reading skill, and be developed further.

\section{CONCLUSION}

Being able to read the Quran fluently and correctly is the goal to achieve by the Islamic Religious Education subject in Indonesia, as it is implemented in 14 years of elementary education in Indonesia. However, a preliminary research result showed that most of the students of a university in Sumedang Regency, West Java, Indonesia, were not able to read Quran fluently and correctly. To address this issue, a reflective-critical action research was done collaboratively by implementing TAHQIQ approach of Quran learning to students of a university in Sumedang Regency. The results showed that students' improvement skill rate reached $90.2 \%$. Moreover, the success rate, which is seen from the students' improvement from non-fluent to fluent level, reached $65.08 \%$. Seeing these figures, it is expected that this research results can be used as one of the alternatives of eradicating the ignorance of reading or illiteracy of the Quran at university level.

\section{SUGGESTIONS}

Based on the results of this research, it is suggested to review and refine the education system of Quran learning in formal schools in Indonesia. This is considered essential as the fact shows that making students fluent in reading Quran based on minimal standard of Arabic language has not been considered not effective. Moreover, follow-up research on students' understanding towards Quran text is suggested to be done to provide more perspective on developing a Quran learning method that meets current need. 


\section{REFERENCES}

Al-Shatibi, A. I. (2003). Al-muwafaqat fi usul al-Shariah. Beirut: Dar qutub al-ilmiyyah.

Aliyah, S. (2017). Peningkatan Aktivitas dan Hasil Belajar Membaca Al Qur'an tentang Perintah Menjaga Kelestarian Alam Melalui Teknik Mind Mapping pada Siswa Kelas XI IPS2 SMA 1 Cepiring Semester 2 Tahun Pelajaran 2015-2016. Nadwa: Jurnal Pendidikan Islam, 11(1), 43-66.

Avalos, B. (2011). Teacher Professional Development in Teaching and Teacher Education over Ten Years. Teaching and teacher education, 27(1), 10-20.

Aziz, K., \& Ambreen, S. (2017). Roadmap for Ensuring Good Governance in Islamic Perspective. FWU Journal of Social Sciences, 11(1), 331-339.

Clarke, D., \& Hollingsworth, H. (2002). Elaborating a Model of Teacher Professional Growth. Teaching and teacher education, 18(8), 947-967.

Creswell, J. W. (2015). Educational Research: Planning, Conducting, and Evaluating Quantitative and Qualitative Research, Enhanced Pearson eText with Loose-Leaf Version--Access Card Package. Pearson Education, Inc.

Daradjat, Z. (2014). Metodik Khusus Pengajaran Agama Islam: Bumi Aksara.

Feldman, A. (1999). The role of conversation in collaborative action research. Educational action research, 7(1), 125-147.

Gibbs, P., Cartney, P., Wilkinson, K., Parkinson, J., Cunningham, S., James-Reynolds, C., . . . Pitt, A. (2017). Literature Review on the Use of Action Research in Higher Education. Educational Action Research, 25(1), 3-22. doi:10.1080/09650792.2015.1124046

James, M., \& McCormick, R. (2009). Teachers Learning how to Tearn. Teaching and teacher education, 25(7), 973-982.

Jamhuri, M. J. M. (2017). Penggunaan Metode Drill Dalam Meningkatkan Kemampuan Membaca Al-Qur'an Siswa Di SMK Dewantoro Purwosari. al-Murabbi, 1(2), 201-216.

Jefferson, R. N. (2014). Action Research: Theory and Applications. New Review of Academic Librarianship, 20(2), 91-116. doi:10.1080/13614533.2014.921536

Joyce, B., Weil, M., \& Calhoun, E. (2003). Models of teaching: Pearson Education, Inc.

Konantz, E. (2012). The Effects of Music on Memory for a Word List. The Huron University College Journal of Learning and Motivation, 50(1), 1-16.

Marrow, A. J. (1977). The practical theorist: The life and work of Kurt Lewin: Teachers College Press.

Messiou, K. (2018). Collaborative Action Research: Facilitating Inclusion in Schools. Educational Action Research, 1-13. doi:10.1080/09650792.2018.1436081 
Muhammad, A., ul Qayyum, Z., Tanveer, S., Martinez-Enriquez, A., \& Syed, A. Z. (2012). E-hafiz: Intelligent System to Help Muslims in Recitation and Memorization of Quran. Life Science Journal, 9(1), 534-541.

Mukminin, A., Rohayati, T., Putra, H. A., Habibi, A., \& Aina, M. (2017). The Long Walk to Quality Teacher Education in Indonesia: Student Teachers' Motives to Become a Teacher and Policy Implications. Ilkögretim Online, 16(1), 35-59.

Shihab, M. Q. (2007). "Membumikan" Al-Quran: fungsi dan peran wahyu dalam kehidupan masyarakat: Mizan Pustaka.

Suyuthi, J. A. (2010). al Itqan fi Ulumil Qur'an: Beirut: Dar al Kutub al Ilmiyyah.

Syarifuddin, A. (2004). Mendidik anak: membaca, menulis dan mencintai Al-Quran: Gema Insani.

Wallace, W. T. (1994). Memory for Music: Effect of Melody on Recall of Text. Journal of Experimental Psychology: Learning, Memory, and Cognition, 20(6), 1471-1485.

Yunus, M. (1983). Metodik Khusus Pendidikan Agama. Jakarta: Hidakarya Agung.

Yusof, R. J. R., Zainuddin, R., \& Yusoff, Z. M. (2011). Learning Methods and Problems of Qur'an Reciters (maLays and africans). QURANICA-International Journal of Quranic Research, 1(1), 17-38. 